\title{
FDI drivers and establishment mode choice of emerging-market MNEs: the role of state ownership
}

\section{Diego Quer*, Laura Rienda and Rosario Andreu}

Department of Management, University of Alicante, P.O. Box 99, E-03080 Alicante, Spain

Email: diego.quer@ua.es

Email: laura.rienda@ua.es

Email: rosario.andreu@ua.es

*Corresponding author

\begin{abstract}
Drawing on an institutional perspective, this study analyses how state ownership affects the relationship between foreign direct investment (FDI) drivers and establishment mode choice of emerging-market multinational enterprises (EMNEs). We argue that state-owned EMNEs encounter stronger institutional pressures in technology- and natural resource-rich countries derived from concerns about takeovers of local companies. Moreover, in low-growth markets, state-owned EMNEs do not always behave as pure profitmaximisers since they are usually subject to home government institutional influences and pursue policy goals. For these reasons, we hypothesise that their choice between acquisitions and greenfield investments differs from that of privately-owned EMNEs. Our analysis of 643 FDIs undertaken by Chinese companies confirms that state-owned EMNEs are less likely to choose acquisitions in host countries with a higher technology and natural resource endowment. However, the relationship between host market growth and establishment mode is not influenced by state ownership.
\end{abstract}

Keywords: establishment mode; EMNEs; FDI drivers; state ownership.

Reference to this paper should be made as follows: Quer, D., Rienda, L. and Andreu, R. (2020) 'FDI drivers and establishment mode choice of emergingmarket MNEs: the role of state ownership', European J. International Management, Vol. 14, No. 1, pp.144-172.

Biographical notes: Diego Quer is an Associate Professor at the Department of Management, University of Alicante, Spain. His main research interests deal with international management and emerging-market multinationals, with a special focus on the Chinese context. His publications have appeared in Asia Pacific Journal of Management, International Business Review, Family Business Review, Journal of the Asia Pacific Economy, Chinese Management Studies, Cross Cultural Management: An International Journal, China: An International Journal and International Journal of Hospitality Management, among others.

Laura Rienda is an Associate Professor at the Department of Management, University of Alicante, Spain. Her primary research interests cover family business management, international management, and business and management in India. Her research has been published in journals like Family Business Review, Asia Pacific Journal of Management, Journal of the Asia Pacific Economy, Chinese Management Studies, Cross Cultural Management: An 
International Journal, Journal of General Management, Journal of Indian Business Research and Journal of Asia Business Studies.

Rosario Andreu is an Associate Professor at the Department of Management, University of Alicante, Spain. Her primary research interests cover tourism management, diversification strategies and international management, with a special focus on Chinese hotel chains. Her research has been published in journals like International Business Review, International Journal of Hospitality Management, Tourism Economics, International Journal of Contemporary Hospitality Management, International Journal of Tourism Research, Journal of China Tourism Research and Enlightening Tourism A Pathmaking Journal.

This paper is a revised and expanded version of a paper entitled 'Establishment mode choice of EMNEs: Does state ownership matter?' presented at the '4 $3^{\text {rd }}$ European International Business Academy (EIBA) Conference', Milan, Italy, December 2017.

\section{Introduction}

A multinational enterprise (MNE) can establish abroad by building a new subsidiary from scratch (greenfield subsidiary) or by acquiring an already existing firm in the host country (acquisition). This is the so-called establishment mode choice that has consequences not only for the foreign investor but also for the host country. A greenfield investment may provide greater contributions to local development. It represents the establishment of a new company, thus generating more opportunities for new job creation than an acquisition, where local facilities and existing jobs are transferred to a foreign acquirer. Consequently, establishment mode choice may have implications in terms of local legitimacy for the foreign company.

Recent literature reviews report several research gaps on the factors affecting establishment mode choice of MNEs (Dikova and Brouthers, 2016; Klier et al., 2017; Slangen and Hennart, 2007). First, the relationship between foreign direct investment (FDI) drivers and the choice between greenfield investments and acquisitions has received scant attention in prior research. Moreover, despite the increasing importance of emerging-market MNEs (EMNEs) in the global landscape, empirical evidence on the determinants of their establishment mode decisions is still scarce. Furthermore, most prior studies on establishment mode choice mainly focused on direct relationships, not addressing the potential effects of interactions between various factors. One of these potential effects refers to the state ownership of the EMNE, a factor that may drive its behaviour.

Over recent years, the internationalisation of state-owned enterprises (SOEs) has become an important phenomenon in international business, thus receiving increasing attention in the literature (Cuervo-Cazurra et al., 2014), in particular, when analysing the behaviour of EMNEs (Hong et al., 2015; Huang et al., 2017; Meyer et al., 2014). SOEs take pre-eminence in emerging markets, with the state being an investor that provides them with the financial resources required to offer needed products and services in an underdeveloped local environment (Cuervo-Cazurra et al., 2016).

In the case of China, SOEs had played a leading role among Chinese MNEs (Sauvant, 2013; Wei, 2010). However, state ownership, considered as an advantage at 
home, may become an obstacle in specific host countries for gaining local legitimacy. FDIs by Chinese SOEs can generate institutional resistance in several host countries because of the competition between the role of the private sector and the government in the economy (Lattemann et al., 2017). In addition, state ownership can be understood as an institutional attribute of acquiring firms accounting for their international behaviour and motivations (Zhang et al., 2011). Thus, the home government may create institutional pressures for state-owned EMNEs to comply with the political objectives of the state and improve geopolitical standing, pushing them to make decisions that deviate from profit-maximising objectives (Hong et al., 2015).

In light of the above, the role of state ownership on establishment mode choice by Chinese MNEs is a research topic that deserves further attention from an institutional perspective. Building on this theoretical framework, Meyer et al. (2014) investigated how Chinese SOEs adapt their establishment mode to institutional pressures in the host country with the aim of building local legitimacy. However, they only focused on technology endowments, not analysing other host country factors that traditionally attract Chinese investments: natural resource endowment and market growth. Therefore, the aim of our paper is to deepen our knowledge of how state ownership affects the relationships between FDI drivers and establishment mode choice of Chinese MNEs. In doing so, we make several contributions to the international business literature.

First, we seek to extend the institutional theory by analysing how the state ownership of the MNE may raise stronger pressures in host countries with a higher technology and natural resource endowment, or may lead the firm to behave not only as a profitmaximiser in low-growth markets, thus affecting establishment mode choice. Second, we provide new insights to the MNEs and public policy analytical framework proposed by Rugman and Verbeke (1998), namely, to the consistency between MNE and host and home country government goals. Third, we contribute to the entry mode choice literature by analysing the influence of FDI drivers on the choice between acquisitions and greenfield investments as well as the potential effect of ownership type. Furthermore, we also contribute to a better understanding of the decision making process of EMNEs, in particular, that leading to choose the establishment mode, which has received little attention in the literature.

The paper is organised as follows. In the next section, we present the theoretical background and develop hypotheses regarding the above-mentioned influence of state ownership on the relationships between FDI drivers and establishment mode choice of EMNEs. The third section explains the data collection process and the variables used in our analysis. The fourth section reports the main findings. Finally, we present a discussion of our results as well as provide some concluding remarks and suggestions for future research.

\section{Theory and hypotheses development}

Institutional theory emphasises the role of political, social, and economic systems surrounding firms in shaping their behaviour (North, 1990). Drawing on this perspective, several scholars argue that foreign investors have to accommodate to the institutional pressures they are exposed in host countries to build local legitimacy (Kostova, 1999; Kostova and Roth, 2002; Kostova et al., 2008; Xu and Shenkar, 2002). However, institutional pressures on foreign investors do not apply homogenously to all foreign firms and may depend on ownership type (Cui and Jiang, 2012). Actually, SOEs usually 
face greater institutional pressures in host countries given that they can be perceived not only as purely economic agents but also as political agents of their home government, thus being considered as a potential threat to the host country's national security (Globerman and Shapiro, 2009). Therefore, SOEs, in comparison to privately-owned firms, are more commonly blocked when they bid for assets that are considered strategic by the host government, such as technologies, natural resources or utilities (CuervoCazurra et al., 2014).

In order to respond to such host country institutional pressures and enhance their legitimacy, SOEs should adapt their operation strategies, including establishment mode decisions, trying to avoid adverse reactions by local interest groups, such as those derived from takeovers of local firms (Meyer et al., 2014). Greenfield investments provide greater opportunities to build local legitimacy since, by creating a new subsidiary from scratch, the foreign MNE can generate additional employment and development in the host country. As a consequence, SOEs may prefer greenfield investments over acquisitions to avoid the controversy associated with a SOE acquiring a local company and transferring existing facilities to a foreign government (Cuervo-Cazurra et al., 2014).

In the case of Chinese MNEs, state ownership may affect not only the level of institutional pressures in the host country and the need for additional efforts to gain local legitimacy. The internationalisation patterns and strategies of Chinese MNEs are institutionally embedded, in particular because of home country factors (Quer et al., 2015). Accordingly, the institutional theory has been extensively used for analysing entry mode choice by Chinese MNEs. Prior studies focused not only on the above-mentioned efforts to attain institutional legitimacy in the host country (Cui and Jiang, 2010), but also on the influence of government ownership and legislative connections (Pan et al., 2014) and the pressures to conform to the home country institutional environment (Deng, 2009). With regard to FDI drivers, several studies draw also on an institutional perspective analysing the moderating influence of host country institutional environments on the relationship between strategic motives and ownership level in overseas subsidiaries (Pan, 2017), and highlighting the role of Chinese government involvement and support in shaping the internationalisation of Chinese MNEs (Wang et al., 2012; Wei et al., 2015). In particular, supportive government policies are reported as important motivators for both strategic asset- and market-seeking FDI of Chinese firms (Lu et al., 2011).

Concerning these FDI drivers, the international business literature assumes that MNEs are profit-maximisers looking to increase their performance as they are seeking strategic assets, natural resources, markets or efficiency (Dunning, 1993). However, this logic does not always apply in the case of state-owned MNEs that may be driven not only by pure business motivations as they are affected by the institutional influence of their home governments. As Cuervo-Cazurra et al. (2014) point out, SOEs may go abroad to achieve political or economic objectives that have little to do with performance gains, such as facilitating institutional relationships between countries or improving the global influence of their home government. This may lead state-owned MNEs to select establishment modes that allow them to reach these political objectives and non-business motivations of their home governments even if such modes do not enable the companies to obtain higher performance.

As for Chinese MNEs, their investments abroad have not been traditionally driven by efficiency. Since China has been itself a low-cost production base, cost reduction has not been a traditional major driver of China's FDI (Cheng and Ma, 2007). Thus, FDI of Chinese MNEs has been mainly driven by strategic asset-, natural resource- or marketseeking motivations (Deng, 2004; Hong and Sun, 2006). As a result, most prior studies 
dealing with China's FDI drivers focused on these three motivations, not addressing efficiency-seeking (Buckley et al., 2007, 2016; Lu et al., 2011; Schüler-Zhou et al., 2012; Wang et al., 2012; Pan, 2017). Therefore, next we propose several hypotheses regarding the impact of these three FDI drivers on establishment mode choice, along with the potential influence of state ownership on those relationships. In doing so, we focus on the three main host country drivers or pull factors that attract Chinese investments: host country's technology endowment, host country's natural resource endowment and host market growth.

\subsection{Host country's technology endowment}

Over recent years, strategic asset-seeking is becoming an increasingly important driver of Chinese FDI (Buckley et al., 2016; Huang and Renyong, 2014; Yang et al., 2014). As a consequence, strategic asset-seeking has been discussed widely in the China's outward FDI literature (Wei, 2010). By accessing advanced technology or managerial know-how, Chinese MNEs try to improve their stock of strategic resources and capabilities in order to overcome their competitive disadvantages vis-à-vis incumbent MNEs from developed countries (Guillén and García Canal, 2009; Luo and Tung, 2007; Meyer, 2015). Hence, by means of this type of strategic asset-seeking FDI, especially in developed countries, Chinese companies explore new opportunities instead of exploiting existing competitive advantages, as conventional theoretical frameworks posit (Hennart, 2012; Mathews, 2006).

Prior studies suggest that the choice between acquisitions and greenfield investments depends on the comparison between the costs associated with the exploitation of existing resources and those associated with the exploration of new resources (Slangen and Hennart, 2007). Whereas greenfield investment is a more efficient way for transferring knowledge and thus exploiting already-existing capabilities, acquisitions are more efficient for strategic asset-augmentation. This is because some types of knowledge are essentially tacit in nature and it is difficult not only to develop them internally but also to access them from outside their owners (Hennart et al., 1996; Hennart and Park, 1993; Larimo 2003).

Moreover, one of the advantages of an acquisition over a greenfield investment is that the former allows a relative quick entry into a foreign market (Globerman and Shapiro, 2009). For this reason, acquisitions have been used by some Chinese MNEs as a faster way to access the technological capabilities they need (Child and Rodrigues, 2005). Actually, EMNEs often consider international expansion as a springboard to obtain strategic assets in order to catch up with their competitors (Luo and Tung 2007). EMNEs are usually latecomers to the industry in which they compete, and they have to accelerate their pace of internationalisation with the aim of accessing resources and capabilities that are not available at home (Mathews, 2002). In other words, EMNEs try to overcome their latecomer disadvantages through aggressive and risk-taking acquisitions (Kedia et al., 2012).

Building on the above-mentioned arguments, there is empirical evidence supporting a positive relationship between strategic asset-seeking and acquisitions as the establishment mode chosen by Chinese MNEs (Anderson and Sutherland, 2015; Deng, 2009; Quer et al., 2017; Rui and Yip, 2008).

However, this general relationship may depend on the ownership type of the foreign acquirer. In some developed countries, several suspicions and concerns about takeovers of domestically owned companies may arise if the foreign company could employ the acquired technological resources for other purposes, thus damaging the international competiveness of the host economy or even imposing a national security threat (Globerman and Shapiro, 2009). This is especially true when the acquirer is a SOE. 
From an institutional standpoint, state ownership may decrease firm's legitimacy in the host country. As Huang et al. (2017) argue, the audience may perceive foreign SOEs as political actors, rather than pure business entities. Accordingly, FDI carried out by these SOEs are likely to be viewed as a negative force threatening security and business interests of the host country, thus leading to increased institutional pressure, such as strict scrutiny from the host government.

Since the early 2000s, the Chinese government has been one of the most important factors boosting the international expansion of Chinese companies, considering it as a key element to ensuring the country's economic growth (Shoham and Rosenboim, 2009). Hence, the business operations of Chinese firms engaged in outward FDI are largely controlled by the government (Wei, 2010). The setting up of overseas operations by Chinese firms became one of the official policies for opening up the economy, with a leading role played by SOEs, which were considered an instrument to achieve national objectives (Zhang and Van den Bulcke, 1996). Actually, Chinese SOEs control around three-quarters of China's outward FDI stock (Sauvant, 2013).

Consequently, concerns arise mainly in host countries with a high technology endowment, not only because their international competiveness may be harmed, but also because the acquired technology may be used for non-commercial purposes, including political objectives of the home country government in the military sector, thus affecting national security. In particular, threats to national security might arise when SOEs pass along their acquired technologies to other firms at home in strategic sectors, such as defence and telecommunications. As a result, acquisitions by SOEs might be viewed as less desirable than those by privately-owned foreign firms (Li et al., 2017).

Therefore, as Cuervo-Cazurra et al. (2014) point out, SOEs are more likely to prefer a greenfield investment over an acquisition, since the former redirects attention towards a foreign government investing in the establishment of new productive facilities in the host country that can create additional employment rather than to the transfer of existing facilities to a foreign government. Moreover, greenfield operations tend to have a lower profile in local media and political discourses compare to acquisitions of local firms, thus reducing the likelihood of being challenged for their legitimacy (Meyer and Thein, 2014).

Following similar arguments from an institutional perspective, Meyer et al. (2014) report that Chinese SOEs, compared with their privately-owned counterparts, encounter stronger institutional pressures in host countries where technology leakage concerns arise. For that reason, they adapt the establishment mode, being less inclined to use acquisitions when they enter technology-rich countries. Similarly, Anderson and Sutherland (2015) find that private Chinese MNEs use aggressive acquisitions rather than greenfield investments to rapidly acquire strategic assets in a developed country like the USA, this propensity not being statistically significant among their Chinese SOEs counterparts. All in all, these arguments lead us to propose:

Hypothesis 1: The higher the host country's technology endowment, the less likely that state-owned EMNEs will choose acquisitions compared to privately-owned EMNEs.

\subsection{Host country's natural resource endowment}

The rapid growth of China's economy since the late 1970s has increased the country's demand of natural resources, making it increasingly dependent on the global supply 
of energy and raw materials (Cheng and Ma, 2007). Thus, the search for natural resources, especially oil, steel, copper and other minerals, has been one of the traditional objectives of China's FDI since the very beginning (Hong and Sun, 2006; Wei, 2010). As a consequence, natural resource endowments in specific host countries have played an important role in attracting Chinese investments (Kolstad and Wiig, 2012; Ramasamy et al., 2012).

Because of the scarcity of natural resources needed to support China's rapid industrialisation, resource exploration has been one of the reasons why the Chinese government has encouraged FDI of Chinese companies under the so-called "go out" policy initiated in the early 2000s (Shoham and Rosenboim, 2009). SOEs in the oil, gas and mining industries have been the leading players among this wave of Chinese MNEs looking for natural resources abroad. Some outstanding examples are: China National Offshore Oil Corporation (CNOOC), which acquired Canada's Nexen energy group; Sinopec, which took over the Swiss-Canadian company Addax Petroleum; or China National Petroleum Corporation (CNPC), that acquired Petrokazakhstan.

As occurs with strategic asset-seeking FDIs, these natural resource-seeking FDIs carried out by SOEs from China and other emerging economies may also raise suspicions in some host countries, thus increasing institutional pressures. Several attempted acquisitions of Western companies by SOEs headquartered in China have raised the opposition of politicians in the host country, resulting in the withdrawal of the takeover bid. The failed acquisitions of the US oil company Unocal and the US mining company Firstgold by $\mathrm{CNOOC}$ and Northwest Nonferrous International Investment Company, respectively, are some high-profile examples (Anderson and Sutherland, 2015).

These concerns are primarily related to government ownership or control of the acquiring companies, which is seen as allowing them to pursue non-commercial objectives that, in turn, impose risks on the host countries. As part of their home-country institutions, Chinese SOEs may be driven by the political interests of the home government, including channelling natural resources back to the domestic economy (Buckley et al., 2007; Child and Rodrigues, 2005; Cui and Jiang, 2012). Specifically, a relevant concern about takeovers of domestically owned companies by Chinese SOEs is that they are acquiring critical natural resources to provide long-run security of supply for China's economy and, in case of an unexpected disruption of supply for those natural resources, Chinese owners would refuse to make supply available to non-Chinese buyers (Globerman and Shapiro, 2009).

This reasoning from an institutional perspective leads us to expect that in countries with abundant natural resources, Chinese SOEs are more likely than their privatelyowned counterparts to contend with host country institutional pressures and they should adapt their operation strategies to gain local legitimacy. Therefore, we predict that Chinese SOEs will be less inclined to use acquisitions as the establishment mode when entering natural resource-rich countries. Thus, we propose:

Hypothesis 2: The higher the host country's natural resource endowment, the less likely that state-owned EMNEs will choose acquisitions compared to privately-owned EMNEs.

\subsection{Host market growth}

Host market growth is one of the location factors that has received much attention in the literature as a pull factor that attracts foreign investments (Dunning, 1980). Prior research 
suggests that FDI flows will be positively associated with demand growth in the host country. The underlying argument is that rapidly growing economies present more opportunities for generating profits than those that are growing slowly or stagnant (Buckley et al., 2007). Since GDP growth rate reflects a host country's economic growth, it has been usually used to assess the potential of the host market (Buckley et al., 2016). Based on this reasoning, Zhang and Daly (2011) argue that more FDI will flow to countries with higher GDP growth rate due to the increasing investment opportunities that arise.

Nevertheless, host market growth rate may affect not only the very decision about making an investment in that country but also the decision about the establishment mode used for such FDI. The choice between acquisitions and greenfield investments is determined by the nature of the assets that the firm wants to exploit or access, and by the location advantages of the host country. Therefore, host market attractiveness has a key influence on establishment mode choice (Demirbag et al., 2008; Morschett et al., 2010).

Several studies argue that, when entering slow-growth markets, MNEs will opt for acquisitions to avoid retaliation by already-established competitors, since these are more likely to respond to greenfield entry as they may lose market share in this case (Caves and Mehra, 1986; Zejan, 1990). By acquiring a competitor, the foreign entrant may reduce competition, whereas a greenfield entry actually creates a new competitor (Hennart and Park, 1993). Acquisitions do not increase production capacity, thus reducing the risk of retaliation from incumbents (Brouthers and Brouthers, 2000). Conversely, high-growth markets can support production capacity growth, making greenfield investments more reasonable (Larimo, 2003). If the market is growing rapidly, the supply increasing features of greenfield investments impose less threat of curbing incumbents' earnings (Dikova and Van Witteloostuijn, 2007). Furthermore, slow-growth markets provide more opportunities to acquire rival firms that are in trouble (Yip, 1982). As a result, there is empirical evidence reporting a negative relationship between host market growth and the choice of acquisitions as the establishment mode (Brouthers and Brouthers, 2000; Larimo, 2003; Rienda et al., 2013), even in the case of Chinese MNEs (Quer et al., 2017).

However, as stated above when analysing other FDI drivers, this general relationship may also depend on the ownership type of the acquirer. The reasoning suggesting that acquisitions are preferred when the host market growth rate is low may apply for marketseeking MNEs that look for profit maximisation, this not always being the case of SOEs. As Cuervo-Cazurra et al. (2014) point out, although some FDIs of SOEs may be carried out with a profitability or market-seeking motive in mind, the home government may, alternatively, induce them to invest abroad to achieve political rather than profitability objectives.

Focusing on the idiosyncrasy of China's institutional framework, Buckley et al. (2007) point out that Chinese MNEs, in particular state-owned ones, show a perverse attitude to risk which contrasts to that of MNEs from industrialised countries. This unconventional behaviour is derived from the fact that Chinese SOEs are usually subject to Chinese government-led institutional influences and they may not be only profitmaximisers. Since the state controls the opportunities given to state-owned EMNEs and shapes their strategic choices, these firms often pursue unconventional non-market strategies (Hong et al., 2015). Similarly, Globerman and Shapiro (2009) posit that SOEs are under relatively low pressure to maximise profits, since they usually pursue policy goals that may allow them to sacrifice performance as conventionally measured. 
Therefore, as stated above, SOEs may choose establishment modes that enable them to achieve the political objectives of their home government even if such modes are risky or do not enable them to achieve profitability. In other words, establishment mode choice may be driven by political calculation rather than by economic consideration (CuervoCazurra et al., 2014). Thus, SOEs may be pushed to behave in an unconventional manner in low-growth markets, choosing greenfield investments instead of the expected acquisitions that reduce the risk of retaliation from incumbents. As a result, we propose:

Hypothesis 3: The lower the host market's growth, the less likely that state-owned EMNEs will choose acquisitions compared to privately-owned EMNEs.

\section{Data and method}

\subsection{Data collection}

To test our hypotheses, we built a dataset of Chinese MNEs using several secondary sources. First, the China Global Investment Tracker, developed by the American Enterprise Institute and the Heritage Foundation, which provides a comprehensive dataset of China's global investments since 2005. Later, we supplemented the data with news items published on Chinese media (such as Xinhua, China Daily and Global Times) as well as with information from each company's corporate website. We excluded sovereign wealth funds, investment funds and financial companies since their FDIs may be driven by specific motivations that might distort our results. Similarly, we ruled out outward FDIs to destinations such as Hong Kong, British Virgin Islands and Cayman Islands, since they serve primarily as financing instruments to invest in third countries or in China itself (Meyer et al., 2014). After exclusion, our final sample consists of 643 FDIs carried out by 273 Chinese non-financial companies in 104 countries between January 2005 and December 2015. Regarding ownership type, 135 companies are SOEs (49.5\%) and $138(50.5 \%)$ are non-SOEs.

As to the establishment mode, it emerges that acquisitions prevail (457 FDIs), accounting for a $71.1 \%$ of the total, whereas greenfield investments account for a $28.9 \%$ (186 FDIs). The top host country is the US, with 86 FDIs, followed by Australia (72), Canada (35), Brazil (27), Russia (23), the UK (22) and Indonesia (21). The main industries are energy $(34.1 \%)$, metals $(21.3 \%)$ and transport $(6.5 \%)$. As for individual companies, CNPC is the top investor, with 42 FDIs, followed by Sinopec (33), CNOOC (17), CITIC Group (12) and China Merchants Group, China Three Gorges Corporation, Fosun and Sinochem (all with ten FDIs each).

Table 1 reports a more detailed description of our dataset, focusing on the whole sample and distinguishing between SOEs and privately-owned firms. First, it is worth mentioning that 419 FDIs were carried out by SOEs, while the remaining 224 were carried out by privately-owned companies. As for FDI profiles, the frequency distributions of establishment modes and destinations are similar, although SOEs are more present in Africa and Latin America, whereas the per cent of FDIs carried out by privately-owned firms in other American countries is higher. This may be related to the industrial distribution of both sub-samples, since FDIs of SOEs belonging to energymaterials industries prevail, whereas there are more FDIs in information-technology industries carried out by non-SOEs. 
Table 1 Detailed description of the dataset

\begin{tabular}{|c|c|c|c|c|c|c|c|c|c|}
\hline \multirow{3}{*}{ Total FDIs } & \multicolumn{3}{|c|}{ Full sample } & \multicolumn{3}{|c|}{ SOES } & \multicolumn{3}{|c|}{ Privately-owned firms } \\
\hline & \multicolumn{2}{|l|}{$N$} & $\%$ & \multicolumn{2}{|l|}{$N$} & \multirow{2}{*}{$\begin{array}{c}\% \\
100\end{array}$} & \multicolumn{2}{|l|}{$N$} & \multirow{2}{*}{$\begin{array}{c}\% \\
100\end{array}$} \\
\hline & 643 & & 100 & 419 & & & 224 & & \\
\hline \multicolumn{10}{|l|}{ Establishment mode } \\
\hline Acquisitions & 457 & & 71.1 & 299 & & 71.4 & 158 & & 70.5 \\
\hline $\begin{array}{l}\text { Greenfield } \\
\text { investments }\end{array}$ & 186 & & 28.9 & 120 & & 28.6 & 66 & & 29.5 \\
\hline \multicolumn{10}{|l|}{ Industry } \\
\hline $\begin{array}{l}\text { Information- } \\
\text { technology }\end{array}$ & 52 & & 8.1 & 15 & & 3.6 & 37 & & 16.5 \\
\hline Energy-materials & 367 & & 57.1 & 292 & & 69.7 & 75 & & 33.5 \\
\hline Other & 224 & & 34.8 & 112 & & 26.7 & 112 & & 50 \\
\hline \multicolumn{10}{|l|}{ Region } \\
\hline Asia & 158 & & 24.6 & 98 & & 23.4 & 60 & & 26.8 \\
\hline Europe & 128 & & 19.9 & 77 & & 18.4 & 51 & & 22.8 \\
\hline $\begin{array}{l}\text { America (not } \\
\text { Latin America) }\end{array}$ & 128 & & 19.9 & 65 & & 15.5 & 63 & & 28.1 \\
\hline Africa & 84 & & 13.1 & 68 & & 16.2 & 16 & & 7.1 \\
\hline Oceania & 81 & & 12.6 & 59 & & 14.1 & 22 & & 9.8 \\
\hline Latin America & 64 & & 9.9 & 52 & & 12.4 & 12 & & 5.4 \\
\hline \multirow{6}{*}{$\begin{array}{l}\text { Top host } \\
\text { countries }\end{array}$} & & $N$ & $\%$ & & $N$ & $\%$ & & $N$ & $\%$ \\
\hline & 1) USA & 86 & 13.4 & 1) Australia & 53 & 12.6 & 1) USA & 53 & 23.7 \\
\hline & 2) Australia & 72 & 11.2 & 2) USA & 33 & 7.9 & 2) Australia & 19 & 8.5 \\
\hline & 3) Canada & 35 & 5.4 & 3) Canada & 27 & 6.4 & 3) India & 14 & 6.2 \\
\hline & 4) Brazil & 27 & 4.2 & 4) Brazil & 21 & 5 & 4) UK & 13 & 5.8 \\
\hline & 5) Russia & 23 & 3.6 & 5) Russia & 17 & 4.1 & 5) Canada & 8 & 3.6 \\
\hline
\end{tabular}

\subsection{Dependent variable}

Establishment mode. The dependent variable in our study is the establishment mode chosen by each company. It was captured by a dummy variable that takes the value of (1) when the Chinese MNE acquired an existing company, and the value of (0) when it made a greenfield investment (Chen et al., 2017; Harzing, 2002; Hennart and Park, 1993; Larimo, 2003; Meyer et al., 2014; Rienda et al., 2013). Following the criteria of some prior studies on establishment mode choice (Barkema and Vermeulen, 1998; Brouthers and Hennart, 2007; Quer et al., 2017), joint ventures have been classified as greenfield investments.

\subsection{Explanatory variables}

Technology endowment. The first explanatory variable is host country technology endowment, measured by the total number of patent applications in the host country divided by the host country's GDP the year before a specific company entered the market 
(with a log transformation) (Buckley et al., 2007, 2016; Meyer et al., 2014). We obtained data on each host country from the World Development Indicators of the World Bank.

Natural resource endowment. The second explanatory variable is host country natural resource endowment, proxied by the percentage of ore and metal exports to total merchandise exports by each host country (log transformation) with one-year lag (Buckley et al., 2007, 2016). Data were also collected from the World Development Indicators of the World Bank.

Market growth. The third explanatory variable is host market growth, measured by GDP growth of each host country with one-year lag (Barkema and Vermeulen, 1998; Boellis et al., 2016; Buckley et al., 2007, 2016; Larimo, 2003). The annual percentage of GDP growth for each host country was also obtained from the World Development Indicators of the World Bank.

\subsection{Moderating variable}

State ownership. We measured state ownership by the percentage of state equity in the firm (Duanmu, 2014; Hong et al., 2015; Huang et al., 2017; Pan et al., 2014).

\subsection{Control variables}

To control for other factors that have been shown in prior studies to influence establishment mode choice, we added several country-, industry- and firm-specific variables.

Labour productivity. As stated above, efficiency-seeking has not been a traditional FDI driver for Chinese firms. However, over recent years labour costs in China are rising and some Chinese companies are transferring their production activities to other locations (Chen, 2015). Therefore, it becomes necessary to control for potential host country drivers of efficiency-seeking FDI. Hence, we considered labour productivity in the host country as a control variable (Dunning, 1980; UNCTAD, 1999). We used GDP per person with a log transformation as a proxy, collecting data from the World Development Indicators of the World Bank. It is worth noting that we did not propose a hypothesis for this variable since we did not find theoretical arguments in line with our remaining hypotheses, i.e., that efficiency-seeking FDI lead firms to choose a specific establishment mode (acquisition or greenfield investment) and that Chinese SOEs show a different behavioural pattern compared to their private counterparts when making that choice.

Cultural distance. Although cultural distance has been extensively used in prior research, there are two opposing arguments regarding its influence on establishment mode choice. Most studies suggest that greater cultural distance discourages the use of acquisitions because the higher costs of managing acquisitions in culturally-distant countries (Kogut and Singh, 1988). In such cases, since the practices of the acquiring and acquired firms are likely to be incompatible and more difficult to transfer, the MNE may prefer a greenfield investment which enable it to introduce its organisational and managerial practices from the outset (Drogendijk and Slangen, 2006). This negative relationship between cultural distance and the use of acquisitions has received extensive support in the literature (Dikova and Brouthers, 2016). However, an alternative argument suggests that acquisitions provide local knowledge that may help to reduce the risks associated 
with entry into culturally-distant countries. This may lead the MNE to choose an acquisition, despite the great cultural distance (Brouthers and Brouthers, 2000; Rienda et al., 2013). Furthermore, it has been argued that home and host country context might be more important explanatory variables of establishment mode choice than cultural distance (Harzing and Pudelko, 2016). With regard to Chinese MNEs, the scant empirical evidence reported a not significant influence of cultural distance on establishment mode choice (Anderson and Sutherland, 2015). Anyway, we controlled for the cultural distance between China and each host country using the Kogut and Singh's (1988) index, based on the extended Hofstede's model with six dimensions (Hofstede et al., 2010). This measure has been extensively used in prior studies on establishment mode choice (Estrin et al., 2009; Harzing, 2002; Larimo, 2003; Rienda et al., 2013; Slangen, 2011; Slangen and Hennart, 2008).

Institutional distance. Institutional distance can be defined as "the extent of similarity or dissimilarity between the formal or regulative and the informal or normative and cognitive aspects of institutions of any two countries" (Gaur and Lu, 2007, pp.87-88). Several prior studies reported that institutional distance increases uncertainty, and thus influences ownership strategies of foreign subsidiaries (Gaur and Lu, 2007), equity ownership in foreign acquisitions (Malhotra and Gaur, 2014) or establishment mode choice, leading the company to choose acquisitions instead of greenfield investments (Chen et al., 2017). To control for institutional distance, we used the six dimensions of the Worldwide Governance Indicators (WGI) project developed by Kaufmann et al. (2009) for measuring the governance infrastructure quality of a country: voice and accountability, political stability and absence of violence, government effectiveness, regulatory quality, rule of law, and control of corruption. We calculated the institutional distance between China and each host country in the same way as we assessed cultural distance with Kogut and Singh's (1988) index. This measure has been previously used by Malhotra and Gaur (2014) and Slangen (2011).

Industry. Since our first two hypotheses deal with legitimacy issues related to technology and natural resource endowment that may affect specific industries, we controlled for the potential effect of industry type by including two dummy variables. First, information-technology industry: (1) the firm belongs to an information, technology or telecommunication industry; (0) otherwise. Second, energy-materials industry: (1) the firm belongs to an energy or materials industry; (0) otherwise. Moreover, prior studies suggest that there might be differences among industries when companies choose the establishment mode (Caves, 1982). Thus, Kogut and Singh (1988) report a preference for greenfield investments over acquisitions in manufacturing industries. However, empirical evidence is not conclusive, since other studies did not find a significant relationship between industry type and establishment mode choice (Slangen and Hennart 2008; Quer et al., 2017). For this reason, we included another dummy variable - manufacturing industry -, as follows: (1) the firm belongs to a manufacturing industry; (0) otherwise. In all cases, we based on the two-digit industry classification of the Global Industry Classification Standard (Meyer et al., 2014).

Firm size. Past studies on establishment mode choice included firm size as a proxy for the availability of resources which can be committed. However, there is a lack of clarity in the relationship between firm size and establishment mode choice as reflected in the conflicting results, with some empirical studies reporting that firm size was 
positively related to acquisitions, others reporting a positive relationship with greenfield investments or no relation with establishment mode choice (Dikova and Brouthers, 2016). Similarly, in the case of Chinese MNEs, while Meyer et al. (2014) reported that firm size had a positive and significant effect on acquisitions, other studies did not obtain a significant relationship (Quer et al., 2017). Thus, we considered firm size as a control variable, using the number of employees as a measure, with a log transformation (Boellis et al., 2016; Huang et al., 2017).

Experience. Following Padmanabhan and Cho (1999), we also controlled for several types of firm's international experience: establishment mode experience, general international experience and host country-specific experience. Prior research reports that firms with much experience with a particular establishment mode are more likely to use the same establishment mode in subsequent entries, either because they have developed the abilities required to manage this establishment mode, thus reducing implementation costs, or because they have become isomorphic, copying their past behaviour (Chang and Rosenzweig, 2001; Drogendijk and Slangen, 2006; Padmanabhan and Cho, 1999; Slangen, 2013; Slangen and Hennart, 2008). However, we did not find empirical evidence on this relationship for Chinese MNEs' establishment mode choice. Hence, we considered decision-specific experience as a control variable, distinguishing between acquisition and greenfield experience (Dikova and Van Witteloostuijn, 2007; Drogendijk and Slangen, 2006; Slangen, 2011, 2013; Slangen and Hennart, 2008). In doing so, we employed two dummies, namely acquisition experience and greenfield experience. The first variable takes the value of 1 if the MNE has acquired at least one firm before each entry decision, while the second variable takes the value of 1 if the MNE has at least one greenfield investment before each entry decision (Buckley et al., 2014). Furthermore, we also controlled for firm's general international experience, using the number of prior FDIs carried out by each firm at the time of each entry decision (Barkema and Vermeulen, 1998; Buckley et al., 2014; Slangen and Hennart, 2008) and for host country-specific experience, employing a dummy that takes the value of 1 if the MNE already had investments in the focal host country at the time of foreign entry (Estrin et al., 2009; Nagano, 2013; Slangen, 2011). All experience-related variables refer to the 2005-2015 period.

Destination and year dummies. We also controlled for fixed effects that may arise from host countries, since FDI decisions may be subject to other host-country specific influences (Estrin et al., 2009). In doing so, we included five dummy variables - Europe, America, Africa, Oceania, and Asia -, the latter used as a benchmark (Buckley et al., 2014). Finally, we included eleven year dummies in order to control for potential timevarying influences on establishment mode choice (Barkema and Vermeulen, 1998; Bhaumik and Gelb, 2005; Slangen, 2013; Slangen and Hennart, 2008).

\section{Results}

Table 2 provides descriptive statistics and bivariate correlations between independent variables. To reject that pairwise correlations give rise to multicollinearity, we computed the variance inflation factor (VIF). Since VIF values are all below 10, no serious multicollinearity problems are found (Kutner et al., 2004). 
Table 2 Descriptive statistics and correlations

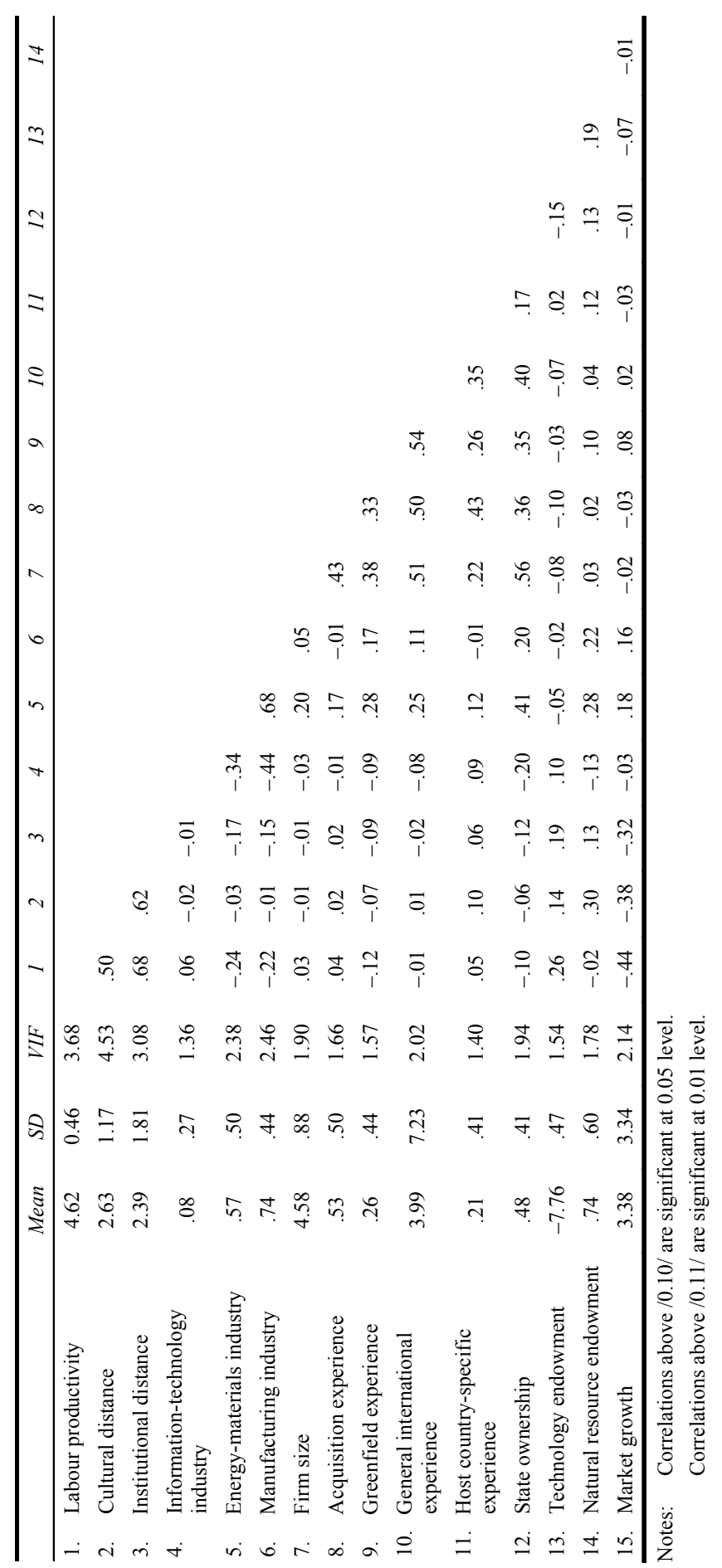


Because the dependent variable is dichotomous, we employed a binary logistic regression to test our hypotheses. Table 3 displays the results with a positive coefficient indicating a preference for an acquisition and a negative coefficient showing a preference for a greenfield investment.

Table 3 Results of logit models for establishment mode choice

\begin{tabular}{|c|c|c|c|c|c|c|}
\hline & Model 1 & Model 2 & Model 3 & Model 4 & Model 5 & Model 6 \\
\hline \multicolumn{7}{|l|}{ Control variables } \\
\hline Labour productivity & $\begin{array}{l}.18 \\
(.37)\end{array}$ & $\begin{array}{l}-.83 \\
(.51)\end{array}$ & $\begin{array}{l}-.90 \dagger \\
(.51)\end{array}$ & $\begin{array}{l}-.98 \dagger \\
(.52)\end{array}$ & $\begin{array}{l}-.82 \\
(.51)\end{array}$ & $\begin{array}{c}-1.01 \dagger \\
(.52)\end{array}$ \\
\hline Cultural distance & $\begin{array}{l}.14 \\
(.18)\end{array}$ & $\begin{array}{l}.35 \dagger \\
(.21)\end{array}$ & $\begin{array}{l}.34 \dagger \\
(.21)\end{array}$ & $\begin{array}{l}.40 \dagger \\
(.21)\end{array}$ & $\begin{array}{l}.36 \dagger \\
(.21)\end{array}$ & $\begin{array}{l}.39 \dagger \\
(.21)\end{array}$ \\
\hline Institutional distance & $\begin{array}{c}.41 * * * \\
(.10)\end{array}$ & $\begin{array}{c}.61 * * * \\
(.12)\end{array}$ & $\begin{array}{c}.63^{* * *} \\
(.12)\end{array}$ & $\begin{array}{c}.64 * * * \\
(.12)\end{array}$ & $\begin{array}{c}.61^{* * *} \\
(.12)\end{array}$ & $\begin{array}{l}.65^{* * *} \\
(.12)\end{array}$ \\
\hline $\begin{array}{l}\text { Information-technology } \\
\text { industry }\end{array}$ & $\begin{array}{l}.66 \\
(.45)\end{array}$ & $\begin{array}{l}.69 \\
(.48)\end{array}$ & $\begin{array}{l}.68 \\
(.49)\end{array}$ & $\begin{array}{l}.76 \\
(.49)\end{array}$ & $\begin{array}{l}.69 \\
(.48)\end{array}$ & $\begin{array}{l}.74 \\
(.49)\end{array}$ \\
\hline $\begin{array}{l}\text { Energy-materials } \\
\text { industry }\end{array}$ & $\begin{array}{l}-.07 \\
(.30)\end{array}$ & $\begin{array}{l}-.09 \\
(.34)\end{array}$ & $\begin{array}{l}-.06 \\
(.34)\end{array}$ & $\begin{array}{l}-.14 \\
(.34)\end{array}$ & $\begin{array}{l}-.09 \\
(.34)\end{array}$ & $\begin{array}{l}-.10 \\
(.34)\end{array}$ \\
\hline $\begin{array}{l}\text { Manufacturing } \\
\text { industry }\end{array}$ & $\begin{array}{l}.32 \\
(.36)\end{array}$ & $\begin{array}{l}.33 \\
(.40)\end{array}$ & $\begin{array}{l}.34 \\
(.40)\end{array}$ & $\begin{array}{l}.39 \\
(.41)\end{array}$ & $\begin{array}{l}.32 \\
(.40)\end{array}$ & $\begin{array}{l}.39 \\
(.41)\end{array}$ \\
\hline Firm size & $\begin{array}{l}-.13 \\
(.14)\end{array}$ & $\begin{array}{l}-.13 \\
(.17)\end{array}$ & $\begin{array}{l}-.12 \\
(.17)\end{array}$ & $\begin{array}{l}-.12 \\
(.17)\end{array}$ & $\begin{array}{l}-.13 \\
(.17)\end{array}$ & $\begin{array}{l}-.11 \\
(.18)\end{array}$ \\
\hline $\begin{array}{l}\text { Acquisition } \\
\text { experience }\end{array}$ & $\begin{array}{l}1.05^{* * *} \\
(.27)\end{array}$ & $\begin{array}{l}.99 * * * \\
(.30)\end{array}$ & $\begin{array}{c}1.02 * * * \\
(.30)\end{array}$ & $\begin{array}{c}1.01 * * * \\
(.30)\end{array}$ & $\begin{array}{l}.99 * * * \\
(.30)\end{array}$ & $\begin{array}{c}1.04 * * * \\
(.30)\end{array}$ \\
\hline $\begin{array}{l}\text { Greenfield } \\
\text { experience }\end{array}$ & $\begin{array}{c}-1.07 * * * \\
(.28)\end{array}$ & $\begin{array}{l}-1.65^{* * *} \\
(.32)\end{array}$ & $\begin{array}{c}-1.66^{* * *} \\
(.32)\end{array}$ & $\begin{array}{c}-1.61 * * * \\
(.32)\end{array}$ & $\begin{array}{c}-1.64 * * * \\
(.32)\end{array}$ & $\begin{array}{c}-1.63 * * * \\
(.32)\end{array}$ \\
\hline $\begin{array}{l}\text { General international } \\
\text { experience }\end{array}$ & $\begin{array}{l}.04 * \\
(.02)\end{array}$ & $\begin{array}{l}.05^{*} \\
(.02)\end{array}$ & $\begin{array}{l}.05^{*} \\
(.02)\end{array}$ & $\begin{array}{l}.05^{*} \\
(.02)\end{array}$ & $\begin{array}{l}.05^{*} \\
(.02)\end{array}$ & $\begin{array}{l}.05^{*} \\
(.02)\end{array}$ \\
\hline $\begin{array}{l}\text { Host country-specific } \\
\text { experience }\end{array}$ & $\begin{array}{l}.09 \\
(.30)\end{array}$ & $\begin{array}{l}.18 \\
(.34)\end{array}$ & $\begin{array}{c}.24 \\
(.34)\end{array}$ & $\begin{array}{l}.20 \\
(.34)\end{array}$ & $\begin{array}{l}.18 \\
(.34)\end{array}$ & $\begin{array}{l}.25 \\
(.34)\end{array}$ \\
\hline \multicolumn{7}{|l|}{ Direct effects } \\
\hline $\begin{array}{l}\text { Technology } \\
\text { endowment }\end{array}$ & & $\begin{array}{l}.28 \\
(.28)\end{array}$ & $\begin{array}{l}.99^{*} \\
(.46)\end{array}$ & $\begin{array}{l}.35 \\
(.29)\end{array}$ & $\begin{array}{l}.27 \\
(.28)\end{array}$ & $\begin{array}{l}.99 * \\
(.47)\end{array}$ \\
\hline $\begin{array}{l}\text { Natural resource } \\
\text { endowment }\end{array}$ & & $\begin{array}{l}.56^{*} \\
(.26)\end{array}$ & $\begin{array}{l}.65^{*} \\
(.27)\end{array}$ & $\begin{array}{c}1.28 * * \\
(.42)\end{array}$ & $\begin{array}{l}.55^{*} \\
(.26)\end{array}$ & $\begin{array}{c}1.31 * * \\
(.44)\end{array}$ \\
\hline Market growth & & $\begin{array}{l}-.05 \\
(.05)\end{array}$ & $\begin{array}{l}-.06 \\
(.05)\end{array}$ & $\begin{array}{l}-.06 \\
(.05)\end{array}$ & $\begin{array}{l}-.04 \\
(.07)\end{array}$ & $\begin{array}{l}-.04 \\
(.07)\end{array}$ \\
\hline \multicolumn{7}{|l|}{ Moderator } \\
\hline State ownership & & $\begin{array}{c}.57 \\
(.38) \\
\end{array}$ & $\begin{array}{c}-10.37 \dagger \\
(5.56) \\
\end{array}$ & $\begin{array}{c}1.41 * * \\
(.54)\end{array}$ & $\begin{array}{l}.69 \\
(.48) \\
\end{array}$ & $\begin{array}{l}-8.58 \\
(5.72) \\
\end{array}$ \\
\hline \multicolumn{7}{|l|}{ Interactions } \\
\hline $\begin{array}{l}\text { Technology endowment } x \\
\text { State ownership }\end{array}$ & & & $\begin{array}{c}-1.41^{*} \\
(.72)\end{array}$ & & & $\begin{array}{c}-1.30 \dagger \\
(.73)\end{array}$ \\
\hline $\begin{array}{l}\text { Natural resource } \\
\text { endowment } x \text { State } \\
\text { ownership }\end{array}$ & & & & $\begin{array}{c}-1.24 * \\
(.56)\end{array}$ & & $\begin{array}{c}-1.17^{*} \\
(.57)\end{array}$ \\
\hline
\end{tabular}


Table 3 Results of logit models for establishment mode choice (continued)

\begin{tabular}{lcccccc}
\hline & Model 1 & Model 2 & Model 3 & Model 4 & Model 5 & Model 6 \\
\hline Market growth $x$ & & & & & -.04 & -.05 \\
State ownership & & & & & $(.09)$ & $(.09)$ \\
Constant & -1.53 & 4.55 & $10.22^{*}$ & 5.11 & 4.40 & $10.06^{*}$ \\
& $(1.67)$ & $(3.56)$ & $(4.59)$ & $(3.61)$ & $(3.57)$ & $(4.64)$ \\
Chi-square & $141.57^{* * *}$ & $157.53^{* * *}$ & $161.57^{* * *}$ & $162.57^{* * *}$ & $157.71^{* * *}$ & $166.11^{* * *}$ \\
Overall \% correct & 76.30 & 80.4 & 80.4 & 81.4 & 80.6 & 81.4 \\
-2 log likelihood & 624.94 & 503.07 & 499.03 & 498.04 & 502.90 & 494.50 \\
Nagelkerke $R^{2}$ & .29 & .35 & .36 & .36 & .35 & .37 \\
\hline
\end{tabular}

Notes: $\quad N=643$. Dependent variable: (1) Acquisition; (0) Greenfield investment.

Standard errors in parentheses. Destination and year dummies are included but not shown.

$\dagger p<.10 ; * p<.05 ; * * p<.01 ; * * * p<.001$.

Model 1 includes only control variables. Model 2 includes the direct effects of the explanatory variables. Models 3, 4 and 5 add the interactions effects of each explanatory variable with the moderator independently, while Model 6 includes all variables and interactions simultaneously. All models turned out to be statistically significant $(p<.001)$.

The interaction term between technology endowment and state ownership is negative and significant in both Models $3(p<.05)$ and $6(p<.10)$. Thus, we find support for Hypothesis 1, that is, Chinese SOEs are less likely than privately-owned firms to acquire local companies when they enter host countries with a high level of technology endowment.

To test Hypothesis 2, we turn to the interaction between natural resource endowment and state ownership, which is negative and statistically significant in both Models 4 and 6 $(p<.05)$. This provides strong support for Hypothesis 2, suggesting that Chinese SOEs are less inclined than their privately-owned counterparts to use acquisitions as the establishment mode in host countries with a high level of natural resource endowment.

In Models 5 and 6, we test Hypothesis 3. The interaction term between host market growth and state ownership is not statistically significant, failing to provide support for Hypothesis 3, which suggested that Chinese SOEs are less likely to choose acquisitions in low-growth markets.

To gain further insight in these interaction effects, we plotted in Figures 1, 2 and 3 the relationships between the three explanatory variables and establishment mode for both state- and privately-owned Chinese MNEs. Based on the findings of Models 3, 4, and 5 , the three figures illustrate the changes in the likelihood of choosing acquisitions instead of greenfield investments when the explanatory and the moderating variables change from their low values (i.e., one standard deviation below the mean) to their high values (i.e., one standard deviation above the mean), keeping all other variables at the mean level.

Figure 1 makes it clear that privately-owned MNEs tend to choose acquisitions when host country technology endowment increases, whereas SOEs tend to choose greenfield investments, providing additional evidence to support Hypothesis 1. Figure 2 shows that when host country natural resource endowment increases, both state- and privately- 
owned MNEs tend to choose acquisitions. However, the positive effect of host country natural resource endowment on the likelihood of acquisition entry is weaker for Chinese SOEs. This provides further support for Hypothesis 2. As graphically illustrated in Figure 3, both privately- and state-owned Chinese MNEs tend to choose acquisitions in low-growth markets, thus not supporting the moderating effect suggested by Hypothesis 3.

Figure 1 Relationship between host country technology endowment and establishment mode for privately- and state-owned EMNEs

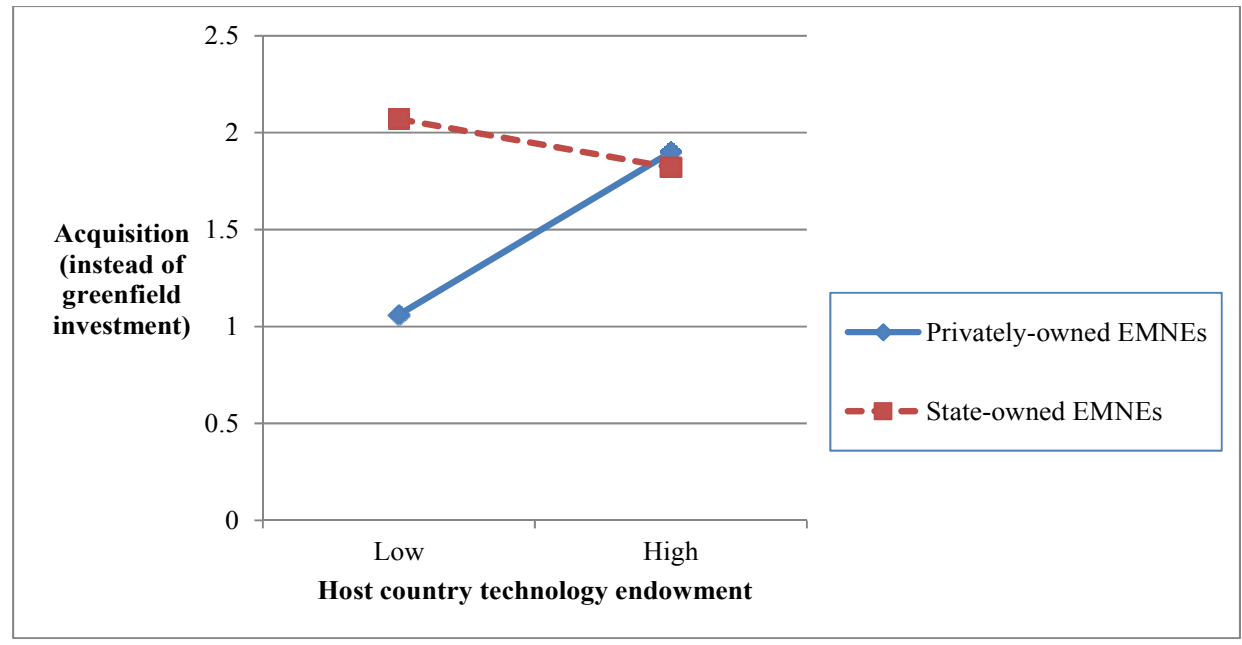

Figure 2 Relationship between host country natural resource endowment and establishment mode for privately- and state-owned EMNEs

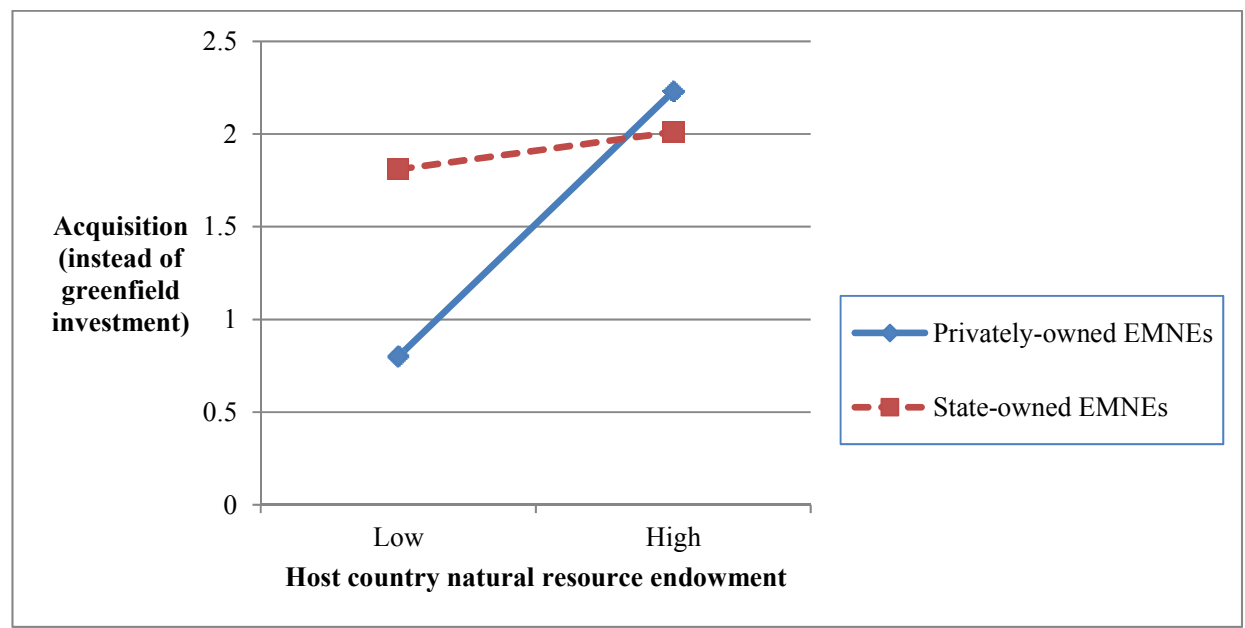


Figure 3 Relationship between host market growth and establishment mode for privately- and state-owned EMNEs

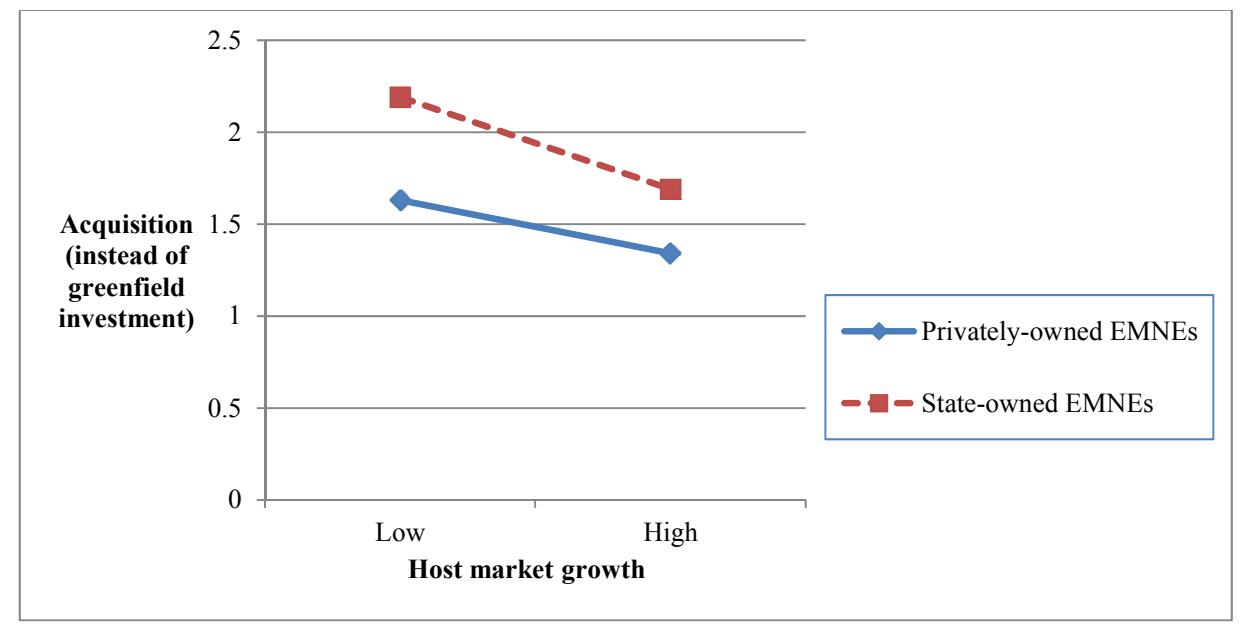

With regard to control variables, we limit the discussion to those that demonstrated significance in all models. First, institutional distance is positively associated with acquisitions. Our finding is in line with the scant prior empirical research that analysed the relationship between institutional distance and establishment mode choice (Chen et al., 2017). Thus, when there is a greater difference in the levels of formal institutional development between China and the host country, Chinese MNEs tend to prefer acquisitions instead of greenfield investments. This provides support for the proposition that acquisitions establishments are less risky than greenfield investments, because an acquisition involves buying an existing company with a team of managers who are familiar with local market conditions, which reduces uncertainty (Dikova and Van Witteloostuijn, 2007).

Second, consistent with several prior studies on establishment mode choice, acquisition experience and greenfield experience show a positive relationship with subsequent acquisition and subsequent greenfield investment, respectively (Dikova and Van Witteloostuijn, 2007; Drogendijk and Slangen, 2006; Padmanabhan and Cho, 1999; Slangen, 2011, 2013; Slangen and Hennart, 2008). This provides support to the abovementioned influence of decision-specific experience, indicating that Chinese MNEs with much experience with a specific establishment mode are more likely to use the same establishment mode in subsequent entries.

Finally, our models also report that general international experience has a direct effect on establishment mode choice. More precisely, Chinese MNEs with more general international experience are more likely to choose acquisitions instead of greenfield establishments. Prior studies on establishment mode choice reached mixed results. Whereas Slangen and Hennart (2008) obtained the same relationship as in our models, others reported just the opposite, i.e., that general international experience increases the likelihood of greenfield entry (Barkema and Vermeulen, 1998; Padmanabhan and Cho, 1999). 


\subsection{Robustness tests}

To assess the sensitive and robustness of our findings, we ran a number of models with alternative measures for some of our variables. First, we replicated the original regression by using a dummy variable as a proxy for the state ownership moderator variable: (1) if the investing company was a SOE and (0) if it was a privately-owned firm (Meyer et al., 2014; Quer et al., 2017). The results of this robustness test, presented in Model 1 of Table 4, confirm those obtained using the percentage of state equity as a measure.

Table 4 Results of logit models for establishment mode choice (robustness tests)

\begin{tabular}{|c|c|c|c|}
\hline & $\begin{array}{l}\text { Model } 1 \\
(S O E= \\
\text { dummy) }\end{array}$ & $\begin{array}{c}\text { Model } 2 \\
\text { (Host country } \\
\text { drivers' alternative } \\
\text { measures) }\end{array}$ & $\begin{array}{c}\text { Model } 3 \\
\text { (Host country drivers } \\
\text { alternative measures; } \\
\text { SOE }=\text { dummy) }\end{array}$ \\
\hline \multicolumn{4}{|l|}{ Control variables } \\
\hline Labour productivity & $\begin{array}{l}-.92 \dagger \\
(.51)\end{array}$ & $\begin{array}{l}-1.05 \dagger \\
(.58)\end{array}$ & $\begin{array}{l}-.66 \\
(.55)\end{array}$ \\
\hline Cultural distance & $\begin{array}{l}.29 \\
(.20)\end{array}$ & $\begin{array}{l}.51 * \\
(.23)\end{array}$ & $\begin{array}{l}.31 \\
(.21)\end{array}$ \\
\hline Institutional distance & $\begin{array}{c}.60 * * * \\
(.12)\end{array}$ & $\begin{array}{l}.56^{* *} \\
(.19)\end{array}$ & $\begin{array}{l}.51 * * \\
(.18)\end{array}$ \\
\hline $\begin{array}{l}\text { Information-technology } \\
\text { industry }\end{array}$ & $\begin{array}{l}.68 \\
(.48)\end{array}$ & $\begin{array}{l}.66 \\
(.51)\end{array}$ & $\begin{array}{l}.68 \\
(.49)\end{array}$ \\
\hline Energy-materials industry & $\begin{array}{l}-.23 \\
(.34)\end{array}$ & $\begin{array}{l}-.00 \\
(.34)\end{array}$ & $\begin{array}{l}-.09 \\
(.32)\end{array}$ \\
\hline Manufacturing industry & $\begin{array}{l}.41 \\
(.40)\end{array}$ & $\begin{array}{l}.14 \\
(.41)\end{array}$ & $\begin{array}{l}.21 \\
(.39)\end{array}$ \\
\hline Firm size & $\begin{array}{l}-.05 \\
(.16)\end{array}$ & $\begin{array}{l}-.14 \\
(.17)\end{array}$ & $\begin{array}{l}-.06 \\
(.16)\end{array}$ \\
\hline Acquisition experience & $\begin{array}{l}1.04 * * * \\
(.29)\end{array}$ & $\begin{array}{l}.95 * * * \\
(.30)\end{array}$ & $\begin{array}{c}.95 * * * \\
(.28)\end{array}$ \\
\hline Greenfield experience & $\begin{array}{c}-1.48 * * * \\
(.32)\end{array}$ & $\begin{array}{l}-1.26 * * * \\
\quad(.32)\end{array}$ & $\begin{array}{c}-1.09 * * * \\
(.30)\end{array}$ \\
\hline $\begin{array}{l}\text { General international } \\
\text { experience }\end{array}$ & $\begin{array}{l}.05^{*} \\
(.02)\end{array}$ & $\begin{array}{l}.05^{*} \\
(.02)\end{array}$ & $\begin{array}{l}.05^{*} \\
(.02)\end{array}$ \\
\hline $\begin{array}{l}\text { Host country-specific } \\
\text { experience }\end{array}$ & $\begin{array}{l}.19 \\
(.33)\end{array}$ & $\begin{array}{l}.20 \\
(.34)\end{array}$ & $\begin{array}{l}.18 \\
(.33)\end{array}$ \\
\hline \multicolumn{4}{|l|}{ Direct effects } \\
\hline Technology endowment & $\begin{array}{l}1.20^{*} \\
(.53)\end{array}$ & $\begin{array}{c}3.92 \\
(3.65)\end{array}$ & $\begin{array}{c}3.28 \\
(3.71)\end{array}$ \\
\hline $\begin{array}{l}\text { Natural resource } \\
\text { endowment }\end{array}$ & $\begin{array}{l}1.75 * * * \\
\quad(.54)\end{array}$ & $\begin{array}{l}.72 \dagger \\
(.38)\end{array}$ & $\begin{array}{l}.49 \\
(.39)\end{array}$ \\
\hline Market growth & $\begin{array}{l}-.07 \\
(.07)\end{array}$ & $\begin{array}{l}-.43 \\
(.43)\end{array}$ & $\begin{array}{l}-.58 \\
(.47)\end{array}$ \\
\hline \multicolumn{4}{|l|}{ Moderator } \\
\hline State ownership & $\begin{array}{l}-6.54 \\
(4.53)\end{array}$ & $\begin{array}{l}-5.45 \dagger \\
(2.86)\end{array}$ & $\begin{array}{c}-4.88 * \\
(2.41)\end{array}$ \\
\hline
\end{tabular}


Table 4 Results of logit models for establishment mode choice (robustness tests) (continued)

\begin{tabular}{lccc}
\hline Model 1 & $\begin{array}{c}\text { Model 2 } \\
\text { (SOE }= \\
\text { dummy) }\end{array}$ & $\begin{array}{c}\text { (Host country } \\
\text { drivers' alternative } \\
\text { measures) }\end{array}$ & $\begin{array}{c}\text { Model 3 } \\
\text { (Host country drivers, } \\
\text { alternative measures; } \\
\text { SOE }=\text { dummy) }\end{array}$ \\
\hline Interactions & & & \\
\hline Technology endowment $x$ & $-1.0{ }^{\dagger} \dagger$ & $-8.30^{*}$ & $-4.92 \dagger$ \\
State ownership & $(.59)$ & $(3.34)$ & $(2.76)$ \\
Natural resource & $-1.46^{* *}$ & $-1.61^{* *}$ & $-.80 \dagger$ \\
endowment $x$ State & $(.55)$ & $(.58)$ & $(.45)$ \\
ownership & .01 & 1.76 & 1.26 \\
Market growth $x$ & $(.08)$ & $(.59)$ & $(.50)$ \\
State ownership & $11.02^{*}$ & 3.60 & 3.43 \\
Constant & $(5.04)$ & $(3.03)$ & $(2.97)$ \\
Chi-square & $164.36^{* * *}$ & $152.60^{* * *}$ & $140.17^{* * *}$ \\
Overall \% correct & 79.70 & 80.6 & 79.9 \\
-2 log likelihood & 531.08 & 496.85 & 541.77 \\
Nagelkerke $R^{2}$ & .35 & .35 & .31 \\
\hline
\end{tabular}

Notes: $\quad N=643$. Dependent variable: (1) Acquisition; (0) Greenfield investment.

Standard errors in parentheses. Destination and year dummies are included but not shown.

$\dagger p<.10 ; * p<.05 ; * * p<.01 ; * * * p<.001$.

We conducted other robustness tests by using alternative measures for the host country drivers considered as explanatory variables in our main analysis. Thus, we used each host country score in the Global Innovation Index (co-authored by Cornell University, INSEAD and the World Intellectual Property Organisation) as a proxy for technology endowment. We proxied natural resource endowment by using the percentage of fuel exports to total exports by each host country (obtained from the World Development Indicators of the World Bank). Finally, the growth of Chinese exports to each host country (collected from the National Bureau of Statistics of China) was used as a proxy for a host market driver. We performed the regressions both by using the percentage of state ownership and the dummy alternative for the moderator variable. The results of these robustness tests, reported in Models 2 and 3 of Table 4, also corroborate our main findings.

\section{Discussion}

The aim of this study has been to investigate whether the establishment mode choice of EMNEs is influenced by the interplay between FDI drivers and ownership type of the investing firm. Our findings support most of the arguments developed above from an institutional perspective.

First, we find that, in host countries with a higher technology endowment, SOEs are less likely to choose an acquisition as the establishment mode compared to non-stateowned firms. Regarding prior research on Chinese MNEs, although Anderson and 
Sutherland (2015) did not find that Chinese SOEs had a greater propensity to engage in strategic asset acquisitions, our finding is indeed consistent with that of Meyer et al. (2014), who found that the higher the host country's technology endowment, the less likely that Chinese SOEs will choose acquisitions compared to non-state-owned Chinese MNEs. Thus, our finding supports the above-mentioned argument suggesting that stateowned EMNEs are subject to stronger institutional pressures in countries where locals may be concerned about technology leakage and, for this reason, they adapt their foreign establishment mode.

Second, we find that, in host countries with a higher natural resource endowment, SOEs are less likely to choose acquisitions compared to privately-owned firms. The scant prior empirical research on Chinese MNEs did not obtain a statistical significance on the relationship between the host country's natural resource endowment and the use of acquisitions (Anderson and Sutherland, 2015). However, our finding reinforces the arguments from an institutional perspective, suggesting that acquisitions by Chinese SOEs may raise concerns in some natural resource-rich host countries derived from the potential political interests of their home government that may include channelling resources back to the home country.

Third, our analysis did not provide empirical support for the proposed influence of state ownership on the relationship between host market growth and establishment mode choice. Therefore, our findings did not allow us to conclude that Chinese SOEs, since they are subject to their home government institutional influences, do not behave as pure profit-maximisers in low-growth host markets where acquisitions might be more reasonable as they do not increase production capacity, thus reducing the risk of retaliation from already established rivals. In addition, the direct effect of host market growth is not statistically significant either. Next we provide some possible explanations for this inconclusive finding.

The potential intensity of competition is only one of the possible factors affecting the relationship between market growth and establishment mode choice. Actually, there is also an argument based on opportunity costs suggesting a positive relationship between host market growth and acquisitions (Brouthers and Brouthers, 2000). Opportunity costs for absent firms are high in fast growing markets (Caves and Mehra, 1986; Hennart and Park, 1993). In such a situation, acquisitions may be preferable since they allow the firm to quickly obtain market share and grasp opportunities (Andersson and Svensson, 1994). As Slangen and Hennart (2007) argue, greenfield investments take time to become operational, and this delay may result in high foregone profits if the market is growing very rapidly, leading the MNE to opt for acquisitions to avoid foregone profits (Caves and Mehra, 1986; Hennart and Park, 1993).

Moreover, Globerman and Shapiro (2009) point out that the presumption suggesting that increased competition is more likely to arise from greenfield investments than from acquisitions of local companies may be simplistic. They argue that a foreign acquisition could make the acquired company a more formidable competitor and that acquisitions might facilitate quicker entry into the host market, thus increasing earlier competition. Actually, there is empirical evidence reporting no difference in the competitive effects from greenfield investments or acquisitions (Chung, 2001).

In any case, the available empirical evidence on the relationship between host market growth and establishment mode choice is fragmented and not conclusive. Whereas some past studies found a negative relationship between host market growth and acquisitions (Brouthers and Brouthers 2000; Larimo 2003; Rienda et al., 2013), others reported not 
conclusive findings (Andersson and Svensson 1994; Barkema and Vermeulen 1998; Boellis et al., 2016; Dikova and Van Witteloostuijn, 2007). Similarly, in the case of Chinese MNEs, although Quer et al. (2017) reported that a higher host economy growth rate was negatively related to Chinese MNEs' preference for acquisitions of local companies, Anderson and Sutherland (2015) failed to obtain statistical significance for such relationship.

\subsection{Contributions}

In our opinion, our paper makes several contributions. From an academic viewpoint, we contribute to the literature on entry mode choice by analysing a topic about which there is still scant evidence: the relationship between FDI drivers and the type of FDI, in particular on the choice between acquisitions and greenfield investments (Gorynia et al., 2005). Moreover, we advance institutional theory in international business research by analysing the influence of state ownership on these relationships. By doing so, we demonstrate how government ownership or control of the acquiring firms may raise concerns and suspicions in host countries, thus leading the MNE to face stronger institutional pressures.

These issues are related to public policies of home and host governments, more precisely, to the consistency between MNE and host and home country government goals as suggested by the MNEs and public policy analytical framework proposed by Rugman and Verbeke (1998). Building upon this framework, Rugman et al. (2014) demonstrate that Chinese MNEs, in particular SOEs, receive substantial support from their home government for international expansion because of goal complementarity; however, when seeking natural resources and strategic assets abroad, they face protectionism from Western governments as their goals are potentially in conflict with those of host governments or are perceived as influential business lobbies in the host economy. Therefore, we contribute to this analytical framework by bringing new insights on the effects of the above-mentioned goal consistency or conflict on establishment mode choice by Chinese MNEs.

Furthermore, as Klier et al. (2017) suggest, the analysis of the contextual factors that intervene in the consistency of the direct relationships is largely missing in the literature on foreign establishment mode choice. Actually, as Slangen and Hennart (2007) point out, some inconsistent findings obtained by prior research on the determinants of establishment mode choice are caused by the existence of moderating effects that have not been considered by the literature. Similarly, Dikova and Brouthers (2016), after reviewing the empirical research on establishment mode choice published between 1980 and 2015, concluded that while most studies analysed only direct relationships, a few of them have recognised that this choice may be more complex, addressing interactions between various factors. Thus, by including the effect of state ownership, we contribute to the establishment mode choice literature, not only analysing the direct effects of FDI drivers on that choice, but also under which firm ownership type (state- or privatelyowned), the influence becomes stronger or weaker.

From an empirical viewpoint, we contribute to a better understanding of the factors influencing decision-making of EMNEs. To date, the empirical study of the motivations for the choice between acquisitions and greenfield investments of EMNEs has received limited attention. Actually, among the empirical studies included in two recent literature reviews on the determinants of establishment mode choice, very few of them dealt with 
MNEs coming from emerging economies. More precisely, only five out of the 31 studies included in the meta-analysis performed by Klier et al. (2017) and only five out of the 75 studies reviewed by Dikova and Brouthers (2016). As for Chinese firms, most of the empirical papers analysing foreign market entry mode have focused on ownership structure decisions, i.e., the choice between full and shared ownership modes, paying less attention to establishment mode choice (Quer et al, 2015). Only a few papers dealt with this research topic in the case of Chinese MNEs (Anderson and Sutherland, 2015; Meyer et al., 2014; Quer et al., 2017; Wu et al., 2012). More precisely, we extend the study of Meyer et al. (2014), who analysed how Chinese SOEs adapt their establishment mode to institutional pressures in technology-rich host countries, by including two other host country drivers of China's FDI: natural resource endowment and market growth.

The study also offers managerial and policy implications. EMNEs are increasingly becoming leading players in many industries. Therefore, both incumbent MNEs and policy makers in host countries need a deeper understanding on how these newcomers make decisions when doing business abroad. Our study provides empirical evidence on their decision-making process leading to choose a specific foreign establishment mode depending on the FDI driver and their state- or privately-owned status. Moreover, our findings show that the influence of home political institutions on the behaviour of SOEs is restricted by the institutional pressures arising in host countries where the sought-after natural resources or strategic assets are considered essential for the local economy. This has to do with public policies and the already mentioned consistency between MNE and host and home government goals. Whereas international expansion of Chinese SOEs is boosted by their home government because of goal complementarity, they face institutional resistance by host governments in specific destinations because of lack of goal consistency. In such situations, Chinese SOEs should adapt their establishment mode in order to attain local legitimacy.

\subsection{Limitations}

Despite these contributions, there are some limitations to our study. First, the use of archival data to construct our explanatory variables precludes capturing perceptions of decision makers on the specific motivations for conducting FDI in certain locations. Second, we considered a single driver for each FDI decision. However, it very well may be that firms select markets not for one reason at a time. Finally, we focused on Chinese MNEs. Hence, the question of whether our findings can be directly generalisable to other EMNEs or whether they are unique to Chinese firms, given some of the idiosyncratic aspects of both their home country involvement as well as host country reaction, remains open.

\subsection{Future research}

Future studies may use survey instruments to collect primary data on managerial perceptions. By doing so, they could discern not only some underlying motivations for each FDI decision, but also the perceived barriers for building local legitimacy in the host country, thus offering more opportunities to advance the institutional theory. The analysis of potential interaction between FDI drivers may be also a fruitful and important avenue for further investigation and extension of the establishment mode choice literature. In addition, future studies may investigate if the behavioural patterns of SOEs originating 
from other emerging economies are similar to those reported in this study. In doing so, they may contribute to the current epistemological debate on the applicability of traditional theoretical underpinnings for explaining the international behaviour of EMNEs.

\section{Conclusion}

This study advances our understanding of the role of state ownership in the relationship between FDI drivers and establishment mode choice by EMNEs. Based on the institutional theory, we investigate whether SOEs adapt their operation strategies to cope with barriers for gaining local legitimacy in host countries and whether they follow a non-conventional behaviour because of the political influence of their home governments. By examining FDIs carried out by Chinese MNEs over the 2005-2015 period, our analysis show that state-owned EMNEs adapt their establishment mode in host countries with a higher technology and natural resource endowment. Specifically, our study highlights that they prefer greenfield investments in order to avoid institutional pressures derived from concerns and suspicions about the takeover of a local company by an acquirer that is actually controlled by a foreign government. However, our findings suggest that home government institutional influences to pursue political objectives do not lead state-owned EMNEs to rule out profit maximisation choosing greenfield investments instead of acquisitions in low-growth markets.

\section{References}

Anderson, J. and Sutherland, D. (2015) 'Entry mode and emerging market MNEs: an analysis of Chinese greenfield and acquisition FDI in the United States', Research in International Business and Finance, Vol. 35, pp.88-103.

Andersson, T. and Svensson, R. (1994) 'Entry modes for direct investment determined by the composition of firm-specific skills', The Scandinavian Journal of Economics, Vol. 96, No. 4, pp.551-560.

Barkema, H.G. and Vermeulen, F. (1998) 'International expansion through start-up or acquisition: a learning perspective', Academy of Management Journal, Vol. 41, No. 1, pp.7-26.

Bhaumik, S.K. and Gelb, S. (2005) 'Determinants of entry mode choice of MNCs in emerging markets: evidence from South Africa and Egypt', Emerging Markets Finance and Trade, Vol. 41, No. 2, pp.5-24.

Boellis, A., Mariotti, S., Minichilli, A. and Piscitello, L. (2016) 'Family involvement and firms' establishment mode choice in foreign markets', Journal of International Business Studies, Vol. 47, No. 8, pp.929-950.

Brouthers, K.D. and Brouthers, L.E. (2000) 'Acquisition or greenfield start-up? Institutional, cultural and transaction cost influences', Strategic Management Journal, Vol. 21, No. 1, pp.89-97.

Brouthers, K.D. and Hennart, J.F. (2007) 'Boundaries of the firm: insights from international entry mode research', Journal of Management, Vol. 33, No. 3, pp.395-425.

Buckley, P.J., Clegg, L.J., Cross, A.R., Liu, X., Voss, H. and Zheng, P. (2007) 'The determinants of Chinese foreign direct investment', Journal of International Business Studies, Vol. 38, No. 4, pp. 499-518.

Buckley, P.J., Elia, S. and Kafouros, M. (2014) 'Acquisitions by emerging market multinationals: implications for firm performance', Journal of World Business, Vol. 49, No. 4, pp.611-632. 
Buckley, P.J., Yu, P., Liu, Q., Munjal, S. and Tao, P. (2016) 'The institutional influence on the location strategies of multinational enterprises from emerging economies: evidence from China's cross-border mergers and acquisitions', Management and Organization Review, Vol. 12, No. 3, pp.425-448.

Caves, R.E. (1982) Multinational Enterprise and Economic Analysis, Cambridge University Press, Cambridge, UK.

Caves, R.E. and Mehra, S.K. (1986) 'Entry of foreign multinationals into US manufacturing industries', in Porter, M.E. (Ed.): Competition in Global Industries, Harvard Business School Press, Boston, MA, pp.449-481.

Chang, S.J. and Rosenzweig, P.M. (2001) 'The choice of entry mode in sequential foreign direct investment', Strategic Management Journal, Vol. 22, No. 8, pp.747-776.

Chen, C. (2015) 'Determinants and motives of outward foreign direct investment by China's provincial firms', Transnational Corporations, Vol. 23, No. 1, pp.1-28.

Chen, R., Cui, L., Li, S. and Rolfe, R. (2017) 'Acquisition or greenfield entry into Africa? Responding to institutional dynamics in an emerging continent', Global Strategy Journal, Vol. 7, No. 2, pp.212-230.

Cheng, L.K. and Ma, Z. (2007) China's Outward FDI: Past and Future, School of Economics, Renmin University of China, Working paper No. 200706001E.

Child, J. and Rodrigues, S.B. (2005) 'The internationalization of Chinese firms: a case for theoretical extension?', Management and Organization Review, Vol. 1, No. 3, pp.381-410.

Chung, W. (2001) 'Mode, size and location of foreign direct investments and industry markups', Journal of Economic Behavior \& Organization, Vol. 45, No. 2, pp.185-211.

Cuervo-Cazurra, A., Ganitsky, J., Luo, Y. and Mezias, J. (2016) 'Global strategy and emerging markets', AIB Insights, Vol. 16, No. 4, pp.3-6.

Cuervo-Cazurra, A., Inkpen, A., Musacchio, A. and Ramaswamy, K. (2014) 'Governments as owners: state-owned multinational companies', Journal of International Business Studies, Vol. 45, No. 8, pp.919-942.

Cui, L. and Jiang, F. (2010) 'Behind ownership decision of Chinese outward FDI: resources and institutions', Asia Pacific Journal of Management, Vol. 27, No. 4, pp.751-774.

Cui, L. and Jiang, F. (2012) 'State ownership effect on firms' FDI ownership decisions under institutional pressure: a study of Chinese outward-investing firms', Journal of International Business Studies, Vol. 43, No. 3, pp.264-284.

Demirbag, M., Tatoglu, E. and Glaister, K.W. (2008) 'Factors affecting perceptions of the choice between acquisition and greenfield entry: the case of Western FDI in an emerging market', Management International Review, Vol. 48, No. 1, pp.5-38.

Deng, P. (2004) 'Outward investment by Chinese MNCs: motivations and implications', Business Horizons, Vol. 47, No. 3, pp.8-16.

Deng, P. (2009) 'Why do Chinese firms tend to acquire strategic assets in international expansion?', Journal of World Business, Vol. 44, No. 1, pp.74-84.

Dikova, D. and Brouthers, K. (2016) 'International establishment mode choice: past, present and future', Management International Review, Vol. 56, No. 4, pp.489-530.

Dikova, D. and Van Witteloostuijn, A. (2007) 'Foreign direct investment mode choice: entry and establishment modes in transition economies', Journal of International Business Studies, Vol. 38, No. 6, pp.1013-1033.

Drogendijk, R. and Slangen, A. (2006) 'Hofstede, Schwartz, or managerial perceptions? The effects of different cultural distance measures on establishment mode choices by multinational enterprises', International Business Review, Vol. 15, No. 4, pp.361-380.

Duanmu, J.L. (2014) 'State-owned MNCs and host country expropriation risk: the role of home state soft power and economic gunboat diplomacy', Journal of International Business Studies, Vol. 45, No. 8, pp.1044-1060. 
Dunning, J.H. (1980) 'Toward an eclectic theory of international production: some empirical tests', Journal of International Business Studies, Vol. 11, No. 1, pp.9-31.

Dunning, J.H. (1993) Multinational Enterprises and the Global Economy, Addison-Wesley, Wokingham, UK.

Estrin, S., Baghdasaryan, D. and Meyer, K.E. (2009) 'The impact of institutional and human resource distance on international entry strategies', Journal of Management Studies, Vol. 46, No. 7, pp.1171-1196.

Gaur, A.S. and Lu, J.W. (2007) 'Ownership strategies and survival of foreign subsidiaries: impacts of institutional distance and experience', Journal of Management, Vol. 33, No. 1, pp.84-110.

Globerman, S. and Shapiro, D. (2009) 'Economic and strategic considerations surrounding Chinese FDI in the United States', Asia Pacific Journal of Management, Vol. 26, No. 1, pp.163-183.

Gorynia, M., Nowak, J. and Wolniak, R. (2005) 'Motives and modes of FDI, firm characteristics and performance: case studies of foreign subsidiaries in Poland', Journal of Transnational Management, Vol. 10, No. 3, pp.55-87.

Guillén, M.F. and García-Canal, E. (2009) 'The American model of the multinational firm and the "new" multinationals from emerging economies', Academy of Management Perspectives, Vol. 23, No. 2, pp.23-25.

Harzing, A.W. (2002) 'Acquisitions versus greenfield investments: international strategy and management of entry modes', Strategic Management Journal, Vol. 23, No. 3, pp.211-227.

Harzing, A.W. and Pudelko, M. (2016) 'Do we need to distance ourselves from the distance concept? Why home and host country context might matter more than (cultural) distance', Management International Review, Vol. 56, No. 1, pp.1-34.

Hennart, J.F. (2012) 'Emerging market multinationals and the theory of the multinational enterprise', Global Strategy Journal, Vol. 2, No. 3, pp.168-187.

Hennart, J.F. and Park, Y.R. (1993) 'Greenfield vs. acquisition: the strategy of Japanese investors in the United States', Management Science, Vol. 39, No. 9, pp.1054-1070.

Hennart, J.F., Larimo, J. and Chen, S.F. (1996) Does National Origin Affect the Propensity of Foreign Investors to Enter the United States Through Acquisitions?, Proceedings of the University of Vaasa, Finland, Discussion paper No. 189.

Hofstede, G., Hofstede, G.J. and Minkov, M. (2010) Cultures and Organizations. Software of the Mind. Intercultural Cooperation and its Importance for Survival, 3rd ed., McGraw-Hill, New York.

Hong, E. and Sun, L. (2006) 'Dynamics of internationalization and outward investment: Chinese corporations' strategies', The China Quarterly, Vol. 187, pp.610-634.

Hong, J., Wang, C. and Kafouros, M. (2015) 'The role of the state in explaining the internationalization of emerging market enterprises', British Journal of Management, Vol. 26, No. 1, pp.45-62.

Huang, X. and Renyong, C. (2014) 'Chinese private firms' outward foreign direct investment: does firm ownership and size matter?', Thunderbird International Business Review, Vol. 56, No. 5, pp.393-406.

Huang, Y., Xie, E., Li, Y. and Reddy, K.S. (2017) 'Does state ownership facilitate outward FDI of Chinese SOEs? Institutional development, market competition, and the logic of interdependence between governments and SOEs', International Business Review, Vol. 26, No. 1, pp.176-188.

Kaufmann, D., Kraay, D. and Mastruzzi, M. (2009) Governance Matters VIII: Aggregate and Individual Governance Indicators 1996-2008, The World Bank, Policy Research Working Paper 4978.

Kedia, B., Gaffney, N. and Clampit, J. (2012) 'EMNEs and knowledge-seeking FDI', Management International Review, Vol. 52, No. 2, pp.155-173.

Klier, H., Schwens, C., Zapkau, F.B. and Dikova, D. (2017) 'Which resources matter how and where? A Meta-analysis on firms' establishment mode choice', Journal of Management Studies, Vol. 54, No. 3, pp.304-339. 
Kogut, B. and Singh, H. (1988) 'The effect of national culture on the choice of entry mode', Journal of International Business Studies, Vol. 19, No. 3, pp.411-432.

Kolstad, I. and Wiig, A. (2012) 'What determines Chinese outward FDI?', Journal of World Business, Vol. 47, No. 1, pp.26-34.

Kostova, T. (1999) 'Transnational transfer of strategic organizational practices: a contextual perspective', Academy of Management Review, Vol. 24, No. 2, pp.308-324.

Kostova, T. and Roth, K. (2002) 'Adoption of an organizational practice by subsidiaries of multinational corporations: Institutional and relational effects', Academy of Management Journal, Vol. 45, No. 1, pp.215-233.

Kostova, T., Roth, K. and Dacin, M.T. (2008) 'Institutional theory in the study of multinational corporations: a critique and new directions', Academy of Management Review, Vol. 33, No. 4, pp.994-1006.

Kutner, M., Nachtsheim, C. and Neter, J. (2004) Applied Linear Regression Models, 4th ed., McGraw-Hill, Irwin.

Larimo, J. (2003) 'Form of investment by Nordic firms in world markets', Journal of Business Research, Vol. 56, No. 10, pp.791-803.

Lattemann, C., Alon, I., Spigarelli, F. and Marinova, S. (2017) 'Dynamic embeddedness in Chinese firm internationalization', Thunderbird International Business Review, Vol. 59, No. 4, pp.547-559.

Li, J., Xia, J. and Lin, Z. (2017) 'Cross-border acquisitions by state-owned firms: how do legitimacy concerns affect the completion and duration of their acquisitions?', Strategic Management Journal, Vol. 38, No. 9, pp.1915-1934.

Lu, J., Liu, X. and Wang, H. (2011) 'Motives for outward FDI of Chinese private firms: firm resources, industry dynamics, and government policies', Management and Organization Review, Vol. 7, No. 2, pp.223-248.

Luo, Y. and Tung, R.L. (2007) 'International expansion of emerging-market enterprises: a springboard perspective', Journal of International Business Studies, Vol. 38, No. 4, pp.481-498.

Malhotra, S. and Gaur, A.S. (2014) 'Spatial geography and control in foreign acquisitions', Journal of International Business Studies, Vol. 45, No. 2, pp.191-210.

Mathews, J.A. (2002) 'Competitive advantages of the latecomer firm: a resource-based account of industrial catch-up strategies', Asia Pacific Journal of Management, Vol. 19, No. 4, 467-488.

Mathews, J.A. (2006) 'Dragon multinationals: new players in 21st century globalization', Asia Pacific Journal of Management, Vol. 23, No. 1, 5-27.

Meyer, K.E. (2015) 'What is “strategic asset seeking FDI'?', Multinational Business Review, Vol. 23, No. 1, pp.57-66.

Meyer, K.E., Ding, Y., Li, J. and Zhang, H. (2014) 'Overcoming distrust: how state-owned enterprises adapt their foreign entries to institutional pressures abroad', Journal of International Business Studies, Vol. 45, No. 8, pp.1005-1028.

Meyer, K.E. and Thein, H.H. (2014) 'Business under adverse home country institutions: the case of international sanctions against Myanmar', Journal of World Business, Vol. 49, No. 1, pp.156-171.

Morschett, D., Schramm-Klein, H. and Swoboda, B. (2010) 'Decades of research on market entry modes: what do we really know about external antecedents of entry mode choice?', Journal of International Management, Vol. 16, No. 1, pp.60-77.

Nagano, M. (2013) 'Similarities and differences among cross-border M\&A and greenfield FDI determinants: evidence from Asia and Oceania', Emerging Markets Review, Vol. 16, pp.100-118.

North, D.C. (1990) Institutions, Institutional Change and Economic Performance, Cambridge University Press, Cambridge, UK. 
Padmanabhan, P. and Cho, K.R. (1999) 'Decision specific experience in foreign ownership and establishment strategies: evidence from Japanese firms', Journal of International Business Studies, Vol. 30, No. 1, pp.25-44.

Pan, Y. (2017) 'Strategic motives, institutional environments, and firm's FDI ownership', Multinational Business Review, Vol. 25, No. 4, pp.307-327.

Pan, Y. Teng, L., Supapol, A.B., Lu, X., Huang, D. and Wang, Z. (2014) 'Firms' FDI ownership: the influence of government ownership and legislative connections', Journal of International Business Studies, Vol. 45, No. 8, pp.1029-1043.

Quer, D., Claver, E. and Rienda, L. (2015) 'Chinese outward foreign direct investment: a review of empirical research', Frontiers of Business Research in China, Vol. 9, No. 3, pp.326-370.

Quer, D., Claver, E. and Rienda, L. (2017) 'Chinese multinationals in Spain: determinants of establishment mode choice’, Cuadernos de Gestión, Vol. 17, No. 2, pp.15-36.

Ramasamy, B., Yeung, M. and Laforet, S. (2012) 'China's outward foreign direct investment: location choice and firm ownership', Journal of World Business, Vol. 47, No. 1, pp.17-25.

Rienda, L., Claver, E. and Quer, D. (2013) 'The internationalisation of Indian multinationals: determinants of expansion through acquisitions', Journal of the Asia Pacific Economy, Vol. 18, No. 1, pp.115-132.

Rugman, A.M. and Verbeke, A. (1998) 'Multinational enterprises and public policy', Journal of International Business Studies, Vol. 29, No. 1, pp.115-136.

Rugman, A.M., Nguyen, Q.T.K. and Wei, Z. (2014) 'Chinese multinationals and public policy', International Journal of Emerging Markets, Vol. 9, No. 2, pp.205-215.

Rui, H. and Yip, G.S. (2008) 'Foreign acquisitions by Chinese firms: A strategic intent perspective', Journal of World Business, Vol. 43, No. 2, pp.213-226.

Sauvant, K.P. (2013) Three challenges for China's outward FDI policy, Columbia FDI Perspectives. Perspectives on topical foreign direct investment issues by the Vale Columbia Center on Sustainable International Investment, No. 106.

Schüler-Zhou, Y., Schüller, M. and Brod, M. (2012) 'Push and pull factors for Chinese OFDI in Europe', in Alon, I., Fetscherin, M. and Gugler, P. (Eds): Chinese International Investments, Palgrave Macmillan, Hampshire, UK, pp.157-174.

Shoham, A. and Rosenboim, M. (2009) 'China's new approach to ODI in Africa: a model for a government seeking natural resources', in Alon, I., Chang. J., Fetscherin, M., Lattemann, C. and McIntyre, J.R. (Eds): China Rules. Globalization and Political Transformation, Palgrave Macmillan, Hampshire, UK, pp.216-230.

Slangen, A.H.L. (2011) 'A communication-based theory of the choice between greenfield and acquisition entry', Journal of Management Studies, Vol. 48, No. 8, pp.1699-1726.

Slangen, A.H.L. (2013) 'Greenfield or acquisition entry? The roles of policy uncertainty and MNE legitimacy in host countries', Global Strategy Journal, Vol. 3, No. 3, pp.262-280.

Slangen, A.H.L. and Hennart, J.F. (2007) 'Greenfield or acquisition entry: a review of the empirical foreign establishment mode literature', Journal of International Management, Vol. 13, No. 4, pp.403-429.

Slangen, A.H.L. and Hennart, J.F. (2008) 'Do multinationals really prefer to enter culturally distant countries through greenfields rather than through acquisitions? The role of parent experience and subsidiary autonomy', Journal of International Business Studies, Vol. 39, No. 3, pp.472-490.

UNCTAD (1999) Foreign direct investment and development, UNCTAD Series on Issues in International Investment Agreements, UNCTAD/ITE/IIT/10 (Vol. I).

Wang, C., Hong, J., Kafouros, M. and Wright, M. (2012) 'Exploring the role of government involvement in outward FDI from emerging economies', Journal of International Business Studies, Vol. 43, No. 7, pp.655-676.

Wei, T., Clegg, J. and Ma, L. (2015) 'The conscious and unconscious facilitating role of the Chinese government in shaping the internationalization of Chinese MNCs', International Business Review, Vol. 24, No. 2, pp.331-343. 
Wei, Z. (2010) 'The literature on Chinese outward FDI', Multinational Business Review, Vol. 18, No. 3, pp.73-112.

Wu, X., Liu, X. and Huang, Q. (2012) 'Impact of the institutional environment on the choice of entry mode: evidence from Chinese enterprises', China: An International Journal, Vol. 10, No. 1, pp.28-50.

Xu, D. and Shenkar, O. (2002) 'Institutional distance and the multinational enterprise', Academy of Management Review, Vol. 27, No. 4, pp.608-618.

Yang, Y., Yang, X., Chen, R. and Allen, J.P. (2014) 'What drives emerging-economy outbound FDI decisions to obtain strategic assets?', Asian Business \& Management, Vol. 13, No. 5, pp.379-410.

Yip, G.S. (1982) 'Diversification entry: internal development versus acquisition', Strategic Management Journal, Vol. 3, No. 4, pp.331-345.

Zejan, M.C. (1990) 'New ventures or acquisitions: the choice of Swedish multinational enterprises', The Journal of Industrial Economics, Vol. 38, No. 3, pp.349-355.

Zhang, H.Y. and Van den Bulcke, D. (1996) 'International management strategies of Chinese multinational firms', in Child, J. and Lu, Y. (Eds): Management Issues in China in the 1990s: International Enterprises, Routledge, London, pp.141-164.

Zhang, X. and Daly, K. (2011) 'The determinants of China's outward foreign direct investment', Emerging Markets Review, Vol. 12, No. 4, pp.389-398.

Zhang, J., Zhou, C. and Ebbers, H. (2011) 'Completion of Chinese overseas acquisitions: institutional perspectives and evidence', International Business Review, Vol. 20, No. 2, pp.226-238 